\title{
STRUCTURAL SOLUTIONS IMPACT ON THERMAL ENERGY EFFICIENCY OF HEATING SURFACE AT AN OPEN SPACE
}

\author{
Dobrosława KACZOREK, Halina KOCZYK \\ Faculty of Civil and Environmental Engineering, Institute of Environmental Engineering, \\ Poznan University of Technology, ul Piotrowo 3a, 60-965 Poznan, Poland
}

Received 14 Nov 2012; accepted 08 Mar 2013

\begin{abstract}
This paper presents studies on thermal energy efficiency of heating surface at an open space according to structural solutions and climatic conditions. Numerical simulation research was conducted to assess three different types of heating surfaces at an open space over chosen period of time in real weather conditions. Performance parameters such as surface temperature, supply temperature and efficiency of heating surface relative to constructional designs and model of control strategy used were analysed. The number, thickness and type of material layers beneath ground level were modified. The distance between heating pipes and their diameters were kept constant. The carried out analyses show that the used solutions can lead to significant differences in the performance and consequently in the energy efficiency of the heating system for open spaces.
\end{abstract}

Keywords: heating surface at an open space; heat transfer; numerical simulations; structural solutions.

Reference to this paper should be made as follows: Kaczorek, D.; Koczyk, H. 2013. Structural solutions impact on thermal energy efficiency of heating surface at an open space, Journal of Civil Engineering and Management 19(6): $883-89$

\section{Introduction}

Moving across surfaces on open spaces covered with snow or ice has different risks. Conventional methods melt snow use of salt, sand or other like gritty material were generally used to remove ice or snow from surfaces. Examples of open spaces are grass covered field such as football, courtyards and pavement surfaces such as roads, drive-up ramps, parking lots, pedestrian walkways, bridge decks, etc.

However, ice will not be melted by the most popularly used salt (sodium chloride) if the temperature falls below $-3.9{ }^{\circ} \mathrm{C}$. In addition, the use of salt can result in concrete corrosion and environmental pollution. Another method like the use of mechanical devices (e.g. snowploughs), can lead to surface and structural damage.

Hence, the highest priority being safety of drivers and pedestrians, and as far as grass surfaces are concerned, e.g. sports fields - extending their period of usability, heating systems for open spaces (hydronic snow melting systems) were introduced, as an alternative to traditional methods (Lund 2000; Liu et al. 2007; Wang et al. 2008; Nagai et al. 2009). In such snow melting heating system the heated fluid is circulated through the pipe circuits, usually laid in a serpentine configuration, just below surface and the heat is transferred from the heat carried fluid to the upper surface by conduction.
The hydronic snow melting heating systems based on low temperature fluid such as geothermal water are used in several countries, for example: in Japan the GAIA system for highway (Morita, Tago 2000), in Switzerland the SERSO system (Lund 2000). At Oklahoma State University the Ground Source Heat Pump (GSHP) based hydronic bridge snow melting system named Smart Bridge was built. Numerous numerical and experimental studies were conducted to investigate the engineered snow melting systems (Kilkis 1994; Chiasson et al. 2000; Rees et al. 2002; Liu et al. 2007). Heat transfer of porous medium and heat transfer on the road by finite element method were analysed in these researches.

The snow melting process on asphalt pavements as solar collector by experiments and numerical simulation were investigated too (Chen et al. 2011; Wu et al. 2009). The effects of thermal conductive asphalt concrete on snow melting performance and asphalt pavement temperature distribution were evaluated and the heat requirement for the snow melting were analysed.

The concrete slab solar collection process, which is one of the essential compositions of road hydronic snow melting system that stores solar energy in summer to melt ice or snow in winter was studied by Gao et al. $(2009,2010)$. These papers studied the heat transfer performance and flow characteristic of hydronic fluid in different spacing pipes. 
All presented studies only consider the application of snow melting system to the asphalt or concrete pavement. As far as we are concern, there are no studies on heating surface covered by grass at an open space.

Determining the heating capacity is the important task in the design of those systems. Unfortunately current guidance in the ASHRAE handbook (ASHRAE 2003) is based on one dimensional steady-state heat transfer at the surface. Like that, many important factors (i.e. transient heat transfer, piping layout and control strategy) that can significantly affects the system performance and system life cycle cost are not taken into account. Therefore, high required investment costs and no reliable design guidelines pose a considerable hurdle to building those systems.

Multiple combinations of performance parameters and adopted constructional designs may lead to substantial differences in thermal energy efficiency of heating surface and thus increase cost of the entire system. Furthermore, thermal analysis of the horizontal surface is often time dependent since the external climate temperature, wind speed, solar radiation vary with time (Banionis et al. 2011, 2012; Tabares-Velasco, Srebric 2012). That is why an efficient and economically viable surface heating system for open space design requires carrying out numerous comparative analyses. Using a numerical model, which can take into account the diversity of adopted constructional designs, and predict the performance of heating surface at an open space under realistic weather conditions enables to find an optimum solution for each and every individual case.

\section{Subject of analysis}

The thermal energy efficiency of a surface heating system for open spaces was determined analytically with use of computer simulation of system under particular weather conditions.

Three types of heating surfaces were considered (Fig. 1). They differed with each other with the type of material layers under the ground level, in the vertical direction. Surface A and surface B were surfaces cove- red with grass. Their construction resembles that of an under pitch heating for football pitches. Surface C covered with $6 \mathrm{~cm}$ thick concrete paving blocks of light grey colour imitated pavement. Surface A and B heating coils were embedded $25 \mathrm{~cm}$ beneath the ground level in a mixture of gravel and soil. In case of stadiums this is the recommended depth due to pitch maintenance services (REHAU 2012). In case of surface $C$ heating coil was located $17 \mathrm{~cm}$ under the ground level in compressed sand in order to comply with design requirements for pavements (Sękowski, Juchnicki 2004). The only difference between surface A and surface B is the $40 \mathrm{~cm}$ thick stabilised earth with concrete, located beneath the heating coils. In case of surface $C$, at depth of $25 \mathrm{~cm}$, another $4 \mathrm{~cm}$ layer of expanded polystyrene was used followed by $40 \mathrm{~cm}$ thick layer of concrete beneath. Material layers beneath heating coils were diversified solely for research purposes as this solution is not practised for open spaces.

Table 1 shows thermal properties of individual materials - based on literature - used in the numerical model (Faraouki 1981; PN-EN ISO 10456:2009). The used values of these parameters correspond to medium-wet conditions.

Table 1. Thermal physical properties of the materials used in the numerical model

\begin{tabular}{|c|c|c|c|}
\hline Material & $\begin{array}{l}\text { Density } \\
{\left[\mathrm{kg} / \mathrm{m}^{3}\right]}\end{array}$ & $\begin{array}{c}\text { Specific heat } \\
\text { capacity } \\
{[\mathrm{J} /(\mathrm{kg} \mathrm{K})]}\end{array}$ & $\begin{array}{c}\text { heat } \\
\text { conduction } \\
{[\mathrm{W} /(\mathrm{m} \mathrm{K})]}\end{array}$ \\
\hline hummus & 1800 & 1260 & 1.1 \\
\hline soil + gravel & 1442 & 1250 & 1.3 \\
\hline $\begin{array}{l}\text { stabilized earth } \\
\text { with concrete }\end{array}$ & 1536 & 1181 & 1.26 \\
\hline concrete & 2400 & 840 & 1.5 \\
\hline $\begin{array}{l}\text { expanded } \\
\text { polistyrene }\end{array}$ & 40 & 1500 & 0.04 \\
\hline native soil & 1800 & 2500 & 1.5 \\
\hline $\begin{array}{l}\text { concrete paving } \\
\text { stones }\end{array}$ & 2200 & 1000 & 1.6 \\
\hline
\end{tabular}
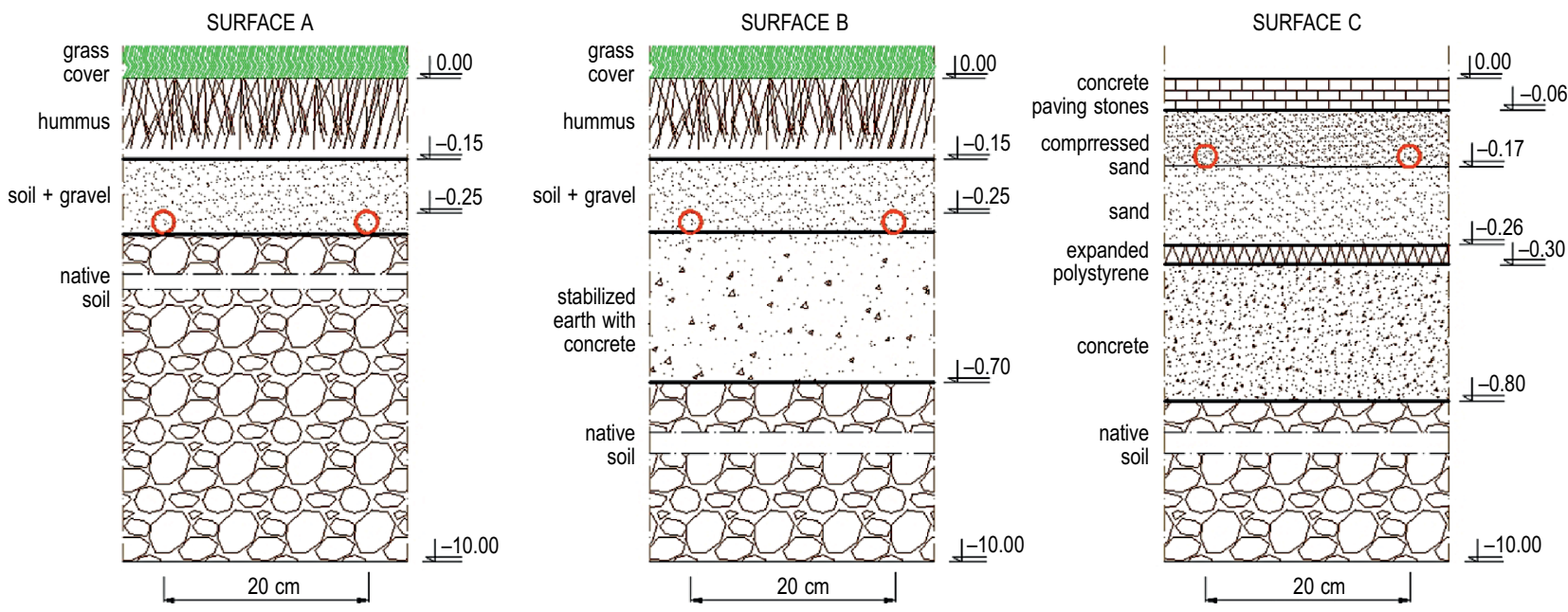

Fig. 1. Profile through the different heating surfaces 
Heating pipes made of cross-linked polyethylene material in $20 \mathrm{~cm}$ spacing laid in a serpentine configuration were used. The outer diameter of pipe was $20 \mathrm{~mm}$, and the inner diameter of pipe was $16 \mathrm{~mm}$. As the heat carrier fluid, circulated in the embedded pipe propylene glycol at $30 \%$ concentration by mass was used.

The analyses were carried out with a control strategy to maintain two surface temperatures $t_{\text {surf }}=3^{\circ} \mathrm{C}$ and $t_{\text {surf }}=5^{\circ} \mathrm{C}$.

In order to have certain parameters for the system - apart from surface temperature - the following assumptions were defined:

- maximum supply temperature $t_{s \max }=45^{\circ} \mathrm{C}$;

- gradient of supply temperature $\mathrm{d} t=0.05{ }^{\circ} \mathrm{C}$ over a single time step;

- indicator of switch on and off the system;

- mean ambient temperature of coils $t_{a m b}$;

- outdoor air temperature deactivating the system $t_{\text {air }}$ $\geq 8{ }^{\circ} \mathrm{C}$

During the operation when the surface temperature dropped below demanded level the controller increased the supply temperature by temperature gradient $\mathrm{d} t=$ $0.05^{\circ} \mathrm{C}$ and turned off the system once the surface temperature reached set value. Several factors determined whether the system was activated or deactivated:

- the outside air temperature;

- surface temperature;

- in case of grass surfaces - temperature of grass roots $t_{\text {roots }}=20^{\circ} \mathrm{C}$, above which the system was deactivated.

Numerical simulations of heating surface behaviour were carried out based on hour-by-hour weather change data recorded for the period from 15 January to $28 \mathrm{Fe}$ bruary 2010 in Poznan, Poland.

\section{Numerical model}

A proprietary numerical model based on explicit finite volume method was used (Chiasson et al. 2000; Incropera, De Witt 1996).

A number of assumptions were made in this model:

- every layers of heating surface are uniform, isotropic and homogeneous;

- snow is treated as the equivalent ice layer, isotropic, homogeneous and uniformed;

- the evaporation of ice in melted process is not considered;

- the penetration of water into heating surface is neglected;

- the temperature and heat flux between layers are continuous completely and heat resistance of contact is not considered.

Described model comprises two modules:

- two-dimensional model of heat conduction in cross-section of heated open surface;

- one-dimensional model of surface conditions, where different surface heat transfer sub-models are applied.
A two-dimensional finite difference mode has been used to calculate conduction heat transfer. As the heating system consists of equally spaced parallel pipes in short hydronic circuits, a two-dimensional representation is deemed as sufficient representation of whole heated open surface.

Variable two-dimensional thermal field in cross-section of heated open surface was determined using the Fourier Eq. (1):

$$
\frac{\partial^{2} T}{\partial x^{2}}+\frac{\partial^{2} T}{\partial y^{2}}=\frac{1}{\alpha} \frac{\partial T}{\partial t}
$$

The finite difference grid used in the model is shown in the Figure 2.

Dimensions of the grid were adapted to pipe radius, the $\Delta x$ dimension was set to be multiplication of pipe radius and $\Pi / 4$, the $\Delta y$ dimension was modified depending on the depth of the node location.

The grid was modified to a little extent, depending on investigated case (type of the heating surface).

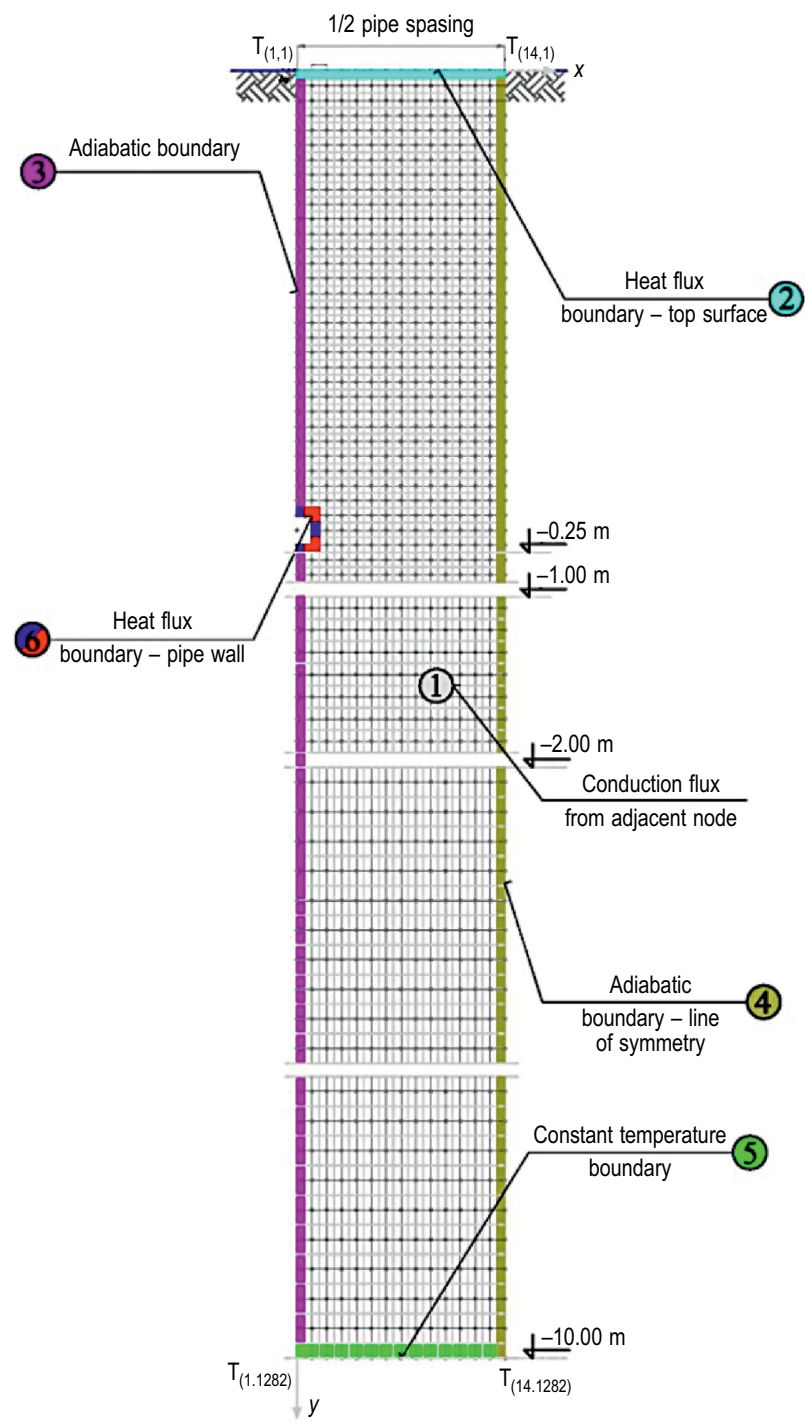

Fig. 2. The finite difference grid with boundary conditions 
Due to symmetry and small temperature differences between adjacent pipes, the model was limited to half the distance between pipes' axes. Nodes were located inside the control volume. Except boundary and surface control volumes, nodes were located at the centre of the wall adjacent to surface or boundary.

The following types of boundary conditions were assumed for the model:

- Dirichlet - first type boundary condition for nodes $10 \mathrm{~m}$ deep in the ground;

- Neumann - second type boundary condition concerning solving for heat flux values for all top surface nodes along with adiabatic conditions for side nodes;

- Fourier - third type boundary condition for nodes surrounding heating pipes, heat flux at the pipe surface nodes represents convection from the heat transfer fluid.

For each node the finite-volume equation was written, using the energy balance method for a control volume about the region, allowing determining temperature at the end of time step. The model was defined by 38 different types of equation. Example of the equation for surface - boundary node (Fig. 3) is given below (Eqn 2):

$$
\begin{aligned}
& t_{x, y}^{\theta}=t_{x, y}+\frac{2 d \theta}{\Delta x_{1} \Delta y_{1} c_{1} \rho_{1}}\left[\frac{\Delta x_{1} \lambda_{1}}{\Delta y_{1}}\left(t_{x+1, y}-t_{x, y}\right)+\right. \\
& \left.\frac{\Delta y_{1} \lambda_{1}}{\Delta x_{1}}\left(t_{x, y-1}-t_{x, y}\right)+q_{\text {surf }}^{\prime \prime} \Delta x_{1}\right],
\end{aligned}
$$

where: $t_{x, y}^{\theta}$ - temperature of the cell at the end of time step, ${ }^{\circ} \mathrm{C} ; t_{x, y}-$ temperature of the cell at the beginning of time step, ${ }^{\circ} \mathrm{C} ; d \theta$ - size of time step, s; $\Delta x_{1}$ - node spacing size in $\mathrm{x}$ direction, $\mathrm{m} ; \Delta y_{1}-$ node spacing size in $y$ direction, $\mathrm{m} ; c_{1} \rho_{1}-$ volumetric capacity of material, $\mathrm{J} /\left(\mathrm{m}^{3} \mathrm{~K}\right) ; \lambda_{1}-$ thermal conductivity of material, $\mathrm{W} /(\mathrm{m} \mathrm{K}) ; q_{\text {surf }}^{\prime \prime}$ - surface heat flux, $\mathrm{W} / \mathrm{m}^{2}$.

Following the classification described by Rees et al. (2002), surface conditions are identified in Table 2.

To provide the finite-volume equations with the appropriate heat flux term at the surface, all different mechanism were considered in the model:

- solar radiation heat flux $\left(q^{\prime \prime}{ }_{\text {solar }}\right)$;

- convective heat flux $\left(q^{\prime \prime}\right.$ convection $)$;

- long-wave radiation heat flux $(q " \mathrm{rad} L W)$;

- heat flux due to evaporation of melted snow and rain $\left(q_{\text {evaporation }}\right)$;

- sensible heat flux due to snowfall $\left(q^{\prime \prime}\right.$ snowfall $)$;

- sensible heat flux due to rainfall $\left(q^{\prime \prime}\right.$ rainfall $)$;

- heat flux due to melting of snow $\left(q^{\prime \prime}{ }_{\text {melt }}\right)$.

The solar radiation heat flux $\left(q^{\prime \prime}\right.$ solar $)$ is the net solar radiation absorbed by the surface and is given by:

$$
q_{\text {solar }}^{\prime \prime}=(1-\alpha) I,
$$

where: $\alpha$-albedo of the surface material; $I$ - total solar radiation, $\mathrm{W} / \mathrm{m}^{2}$.

The convective heat flux ( $q^{\prime \prime}$ convection $)$ and long-wave radiation heat flux $\left(q^{\prime \prime}\right.$ rad $\left.L W\right)$ are given by Eqns 4 and 5 respectively:

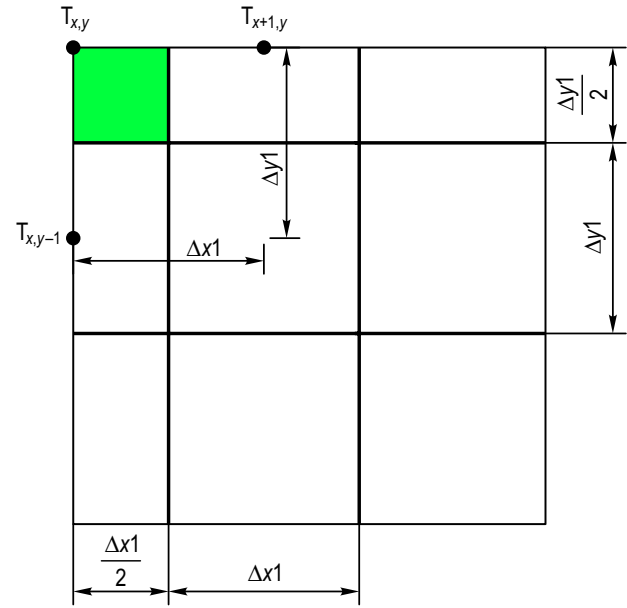

Fig. 3. Cell geometry for surface-boundary node

Table 2. Classification and definition of surface conditions

\begin{tabular}{ll}
\hline $\begin{array}{c}\text { Surface } \\
\text { condition }\end{array}$ & \multicolumn{1}{c}{ Definition } \\
Dry & $\begin{array}{l}\text { The surface is free of liquid and ice. The } \\
\text { pavement surface temperature may be above or } \\
\text { below freezing. }\end{array}$ \\
Wet & $\begin{array}{l}\text { The surface temperature is above freezing and } \\
\text { has some liquid water retained o it. but no } \\
\text { ice. The liquid water can come from rainfall, } \\
\text { condensed vapor, or the melted snow. }\end{array}$ \\
Dry snow & $\begin{array}{l}\text { The surface is covered with dry snow without } \\
\text { liquid. The snow can be regarded as a } \\
\text { porous matrix of ice. The pavement surface } \\
\text { temperature is below freezing so that snow is } \\
\text { not currently being melted. }\end{array}$
\end{tabular}

The surface contains ice crystals that are fully saturated with water. Water penetrates the

Slush only porous matrix of ice from bottom to the upper surface. The pavement surface temperature is at freezing point.

The surface contains snow that is partly

Snow and melted. The lower part of the snow is saturated

slush with water and the upper is as dry snow. The pavement surface temperature is at freezing point.

The ice on the surface is in solid form rather

Solid ice than porous like snow. The pavement surface temperature must be below freezing.

$$
\begin{gathered}
q_{\text {convection }}^{\prime \prime}=h_{c}\left(t_{\text {surf }}-t_{\text {air }}\right) ; \\
q_{\text {rad_LW }}^{\prime \prime}=\varepsilon \sigma\left[\left(t_{\text {sky }}+273,15\right)^{4}-\left(t_{\text {air }}+273,15\right)^{4}\right],
\end{gathered}
$$

where: $h_{c}$ - convection coefficient; $t_{\text {air }}$ - air temperature, ${ }^{\circ} \mathrm{C} ; t_{\text {surf }}$ - surface temperature, ${ }^{\circ} \mathrm{C} ; t_{\text {sky }}$ - sky temperature, ${ }^{\circ} \mathrm{C} ; \varepsilon$ - emissivity coefficient of the surface material; $\sigma-$ Stefan-Boltzmann constant.

The convection heat transfer coefficient is determined with the correlation described by Mihalakakou (2002). The sky temperature is computed from the relationship given by Bliss (1961). 
The heat flux due to evaporation $\left(q^{\prime \prime}\right.$ evaporation $)$ from pavement surface is given by ASHRAE (2003):

$$
q_{\text {evaporation }}^{\prime \prime}=h_{f g} h_{d}\left(w_{\text {air }}-w_{p v}\right) \text {, }
$$

where: $h_{f g}$ - latent heat of vaporization of water, $\mathrm{kJ} / \mathrm{kg}$; $h_{d}$ - mass transfer coefficient, $\mathrm{kg} /\left(\mathrm{m}^{2} \mathrm{~s}\right) ; w_{\text {air }}, w_{p v}-\mathrm{hu}-$ midity ratio of ambient air and the saturated air at the slush surface, $\mathrm{kg}$ (vapor) $/ \mathrm{kg}$ (dry air).

The heat flux due to evaporation $\left(q^{\prime \prime}\right.$ evaporation $)$ from grass cover surface is given by Penman (1948):

$q_{\text {evaporation }}^{\prime \prime}=0,0168 f h_{\text {sur }}\left[\left(a T_{\text {surf }}+b\right)-r_{a}\left(a T_{\text {air }}+b\right)\right],(7)$

where: $a=103 \mathrm{~Pa} / \mathrm{K} ; b=609 \mathrm{~Pa}, 263 \mathrm{~K}<T<303 \mathrm{~K} ; r_{a}-$ relative humidity of the air above the ground surface; $f$ - fraction which depends mainly on the ground cover and on the humidity level of the ground. The fraction $f$ can be estimated as follows:

- for bare soils, $f$ is directly proportional to soil moisture content $(f=1$ for saturated soils; $f=0.6-0.8$ to wet soils; $f=0.4-0.5$ to moist soils; $f=0.1-0.2$ to arid soils;

- for grass covered soils the fraction $f$ is obtained by multiplying 0.7 by the value of $f$ for bare soil depending on the soil moisture content.

Heat flux due to evaporation is considered only if the temperature of top surface node is not less than $0{ }^{\circ} \mathrm{C}$ and there is no snow layer covered on the surface.

The sensible heat flux associated with snowfall $\left(q{ }^{\prime}\right.$ snowfall $)$ and rainfall $\left(q{ }^{\prime \prime}\right.$ rainfall $)$ is given by:

$$
q_{\text {snowfall }}^{\prime \prime} \text { rainf all }=\dot{m}_{p}^{\prime \prime} c_{p}\left(t_{\text {surf }}-t_{\text {air }}\right) \text {, }
$$

where: $\dot{m}_{p}^{\prime \prime}$ - rainfall or snowfall rate in the water equivalent mass per unit time per unit area, $\mathrm{kg} /\left(\mathrm{m}^{2} \mathrm{~s}\right)$; $c_{p}$ - specific heat of snow or rain, $\mathrm{kJ} /(\mathrm{kg} \mathrm{K})$.

The surface temperature can be temperature at the surface, or the temperature at the dry snow surface, or at the freezing point if there is only slush layer on the surface.

The heat flux due to melting snow and ice includes two parts. The sensible heat needed to raise the temperature of snow to $0{ }^{\circ} \mathrm{C}$ which is calculated with following equation:

$$
q_{\text {melt_sen }}^{\prime \prime}=\dot{m}_{\text {melt }}^{\prime \prime} c_{p_{-} \text {snow }}\left(t_{\text {air }}-0\right),
$$

where: $\dot{m}_{m e l t}^{\prime \prime}-$ mass flux of the melted snow, $\mathrm{kg} /\left(\mathrm{m}^{2} \mathrm{~s}\right)$.

The latent heat of fusion given by:

$$
q_{m e l t}^{\prime \prime}{ }_{\text {lat }}=-\dot{m}_{\text {melt }}^{\prime \prime} h_{\text {if }},
$$

where: $h_{i f}-$ latent heat of fusion of water, $\mathrm{J} / \mathrm{kg}$.

The procedure for identifying surface conditions and calculating corresponding heat and mass balance has been described in detail in the literature (Liu et al. 2007; Kaczorek 2011).

This model adopts a successive substitution method to couple the model of two-dimensional heat conduction in cross-section of heated open surface with the model of surface conditions. The heat balance equations can be solved by using the flux conducted through the heated open surface calculated at the previous time step. The fluxes at the surface calculated at the currant time step are than used to set Neumann boundary condition in the two-dimensional model of heat conduction in cross-section of heated open surface.

\section{Experimental setup and methodology}

The experimental setup was built at Poznan University of Technology. It consisted of the external surface with hydronic pipe embedded in it, located on the lawn, at a distance of $4 \mathrm{~m}$ from the experimental building and the heat substation (Fig. 4) inside the experimental building. The size of external surface is $2 \times 2 \mathrm{~m}$. The construction of heating surface (Fig. 1 - heating surface A) was described in details in Section 2. Besides, a $100 \mathrm{~mm}$ thick expanded polystyrene plate was installed on all four sides of the surface to reduce heat loss.

The heat exchanger was used to separate the glycol from the water circuit and like a heat source gas boiler was used.

The images of the particular works of construction are presented in Figure 5.

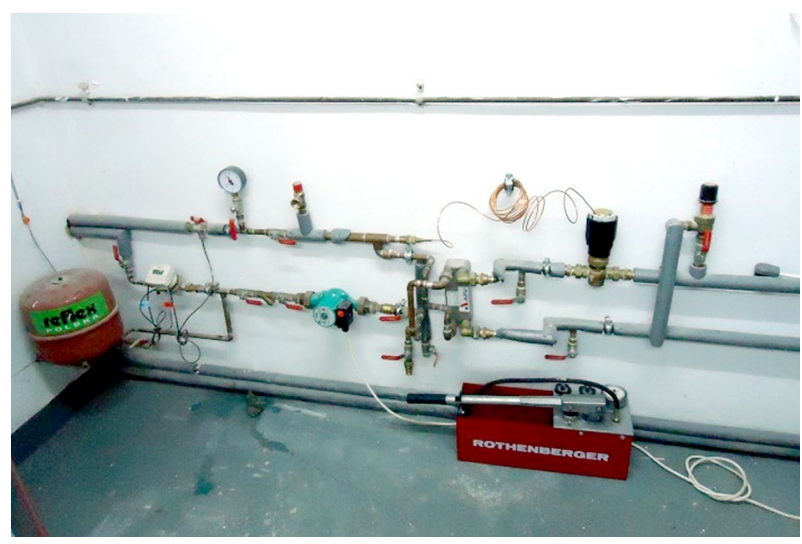

Fig. 4. Heat substation for heating surface at an open space
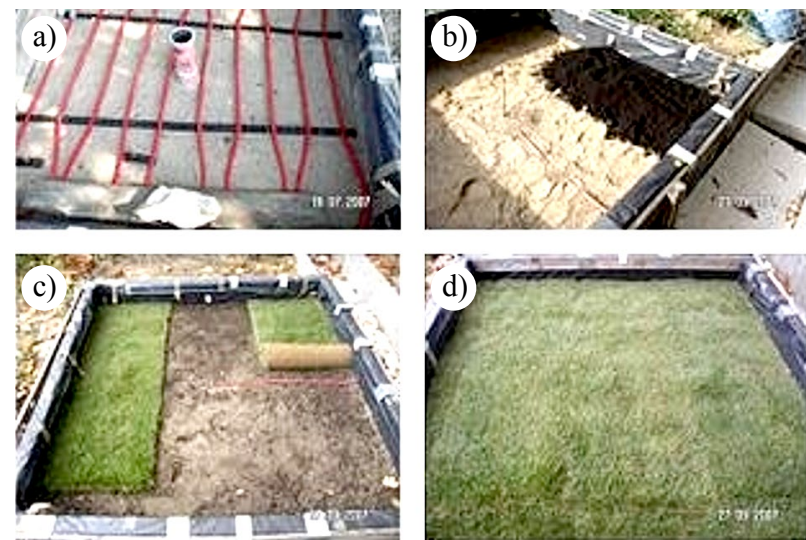

Fig. 5. Images of particular works during the construction of experimental setup: $a$ - fixing pipes; $b$ - surface with thermal sensor; $\mathrm{c}$ - cover with grass; $\mathrm{d}$ - completed surface 
Experiment was conducted from 15 January to 28 February 2010 in real weather conditions. Meteorological data including air temperature, amount of rainfall, wind speed, water vapour pressure, cloud cover, dew point temperature was provided by the Institute of Meteorology and Water Management in Poznan. The local weather station is located approximately $7 \mathrm{~km}$ from the experimental setup. Due to lack of solar radiation data, the total solar radiation was calculated using computational model (Marszałek 1993). This model takes into account the following factors: the geographical longitude and latitude, atmospheric pressure, relative humidity, air temperature, visibility in the atmosphere, cloud cover, albedo (air, surface), type of region and is based on the models developed by Kamada and Flocchini (1986) and Louche et al. (1987).

To measure the temperature at different depths, a type of high precision thermal resistors (Pt 100), with $\pm 0.1{ }^{\circ} \mathrm{C}$ accuracy were used. The temperature of the grass surface was measured by tree thermal resistors, placed in the line perpendicular to the pipes, in the middle of external surface and perfectly covered by the lawn, the height of which was $0.02 \mathrm{~m}$. One sensor was located between the pipes in the centre and the other two above the pipes. The other sensors were located in the centre of the cross section at different depths. For measuring inlet and outlet water temperature the T-type thermocouples, with $\pm 0.5^{\circ} \mathrm{C}$ accuracy were set at the upper wall of pipes.

Accurate sensor locations are shown in Figure 6.

All sensor information was recorded at time intervals of $5 \mathrm{~min}$. Every sensor was connected to a special built data acquisition system located inside the experimental building.

The surface temperature was controlled using a constant supply temperature of $33{ }^{\circ} \mathrm{C}$ in the heating system.

\section{Model comparison with experimental results}

In designing and evaluating the surface heating system performance, it is the calculation of surface temperatures and surface conditions at any given time that is of prime concern.

The test has been conducted by providing weather data, entering fluid temperature and the parameters that describe the simulated heating surface as inputs to the model and comparing the predicted average surface temperature with the corresponding measured values.

Initially, the temperature in the cells surrounding the model boundary was imposed to be equal to the average annual outdoor temperature for the Poznan city. On the surface and in the heating pipes the temperature from measurements registered before switching on the heating surface was assumed. The model was "warm up" until the temperature profile in cross-section of heated open surface reached a state of equilibrium. The assumed equilibrium conditions were obtained when the maximum temperature difference at all levels between two following time steps was less than $0.0001{ }^{\circ} \mathrm{C}$ and temperature
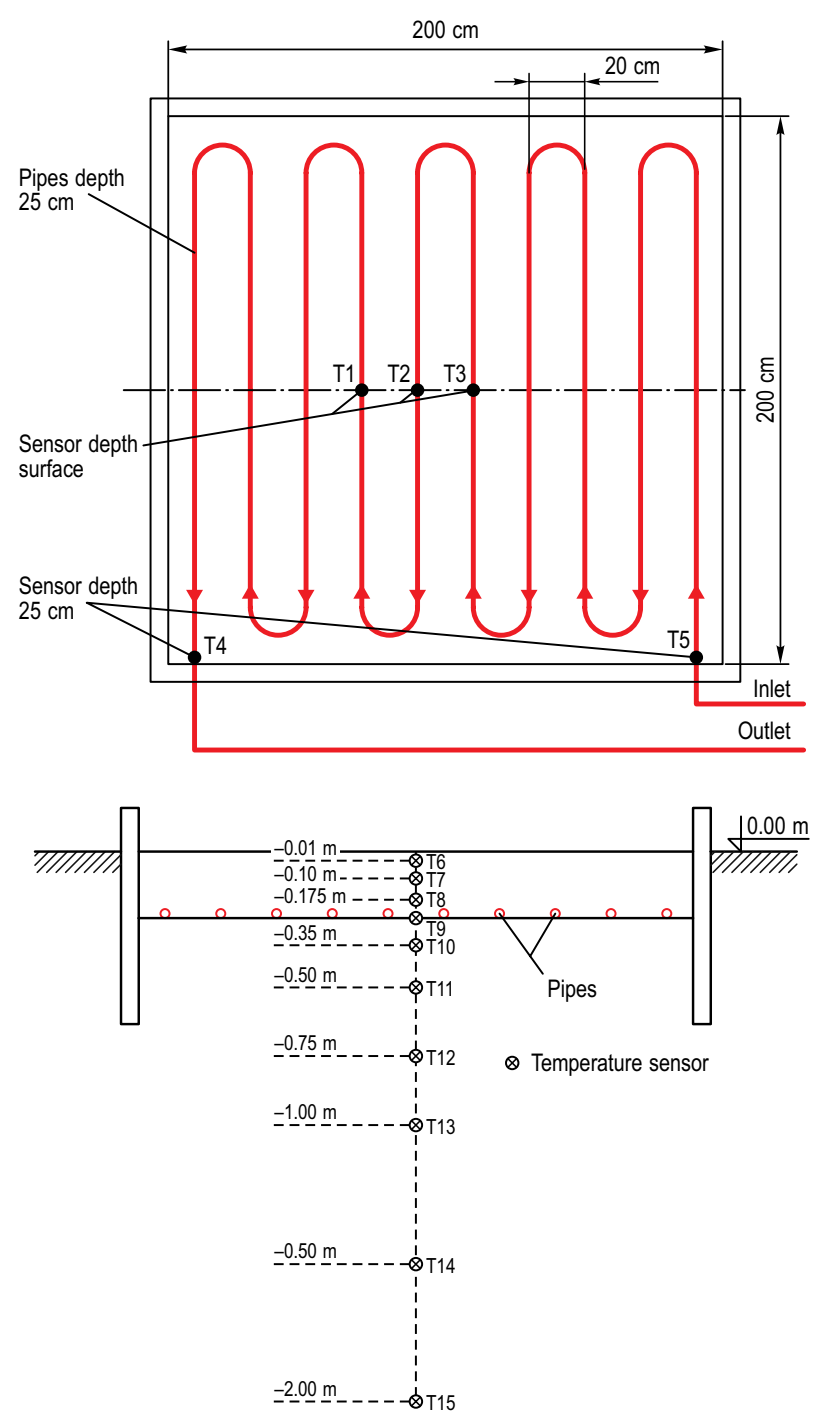

Fig. 6. Schematic of measuring point in tested surface

in the cells located in the same depths as the sensors had the same values. This state was taken as the initial condition and from that moment the numerical simulations of heated open surface under the influence of changing weather conditions started. Measured and predicted average surface temperatures are compared in Figure 7. Solar radiation and the ambient temperature are also indicated on this figure.

Figure 8 shows the predicted mass of accumulated snow on the surface with the snow precipitation rate.

We can see that the surface temperature is dependent on weather conditions. Daily variation of climatic impacts causes significant changes in the temperature of heating system. The heating system was guaranteed its function of maintaining the surface temperature above $0{ }^{\circ} \mathrm{C}$, working with set supply temperature, except when the ambient temperature has decreased below $-15{ }^{\circ} \mathrm{C}$ during the night time and the surface wasn't affected by solar radiation. Clear influence of solar radiation on surface temperature was shown when the surface was cleared of snow. The surface temperature was increased 


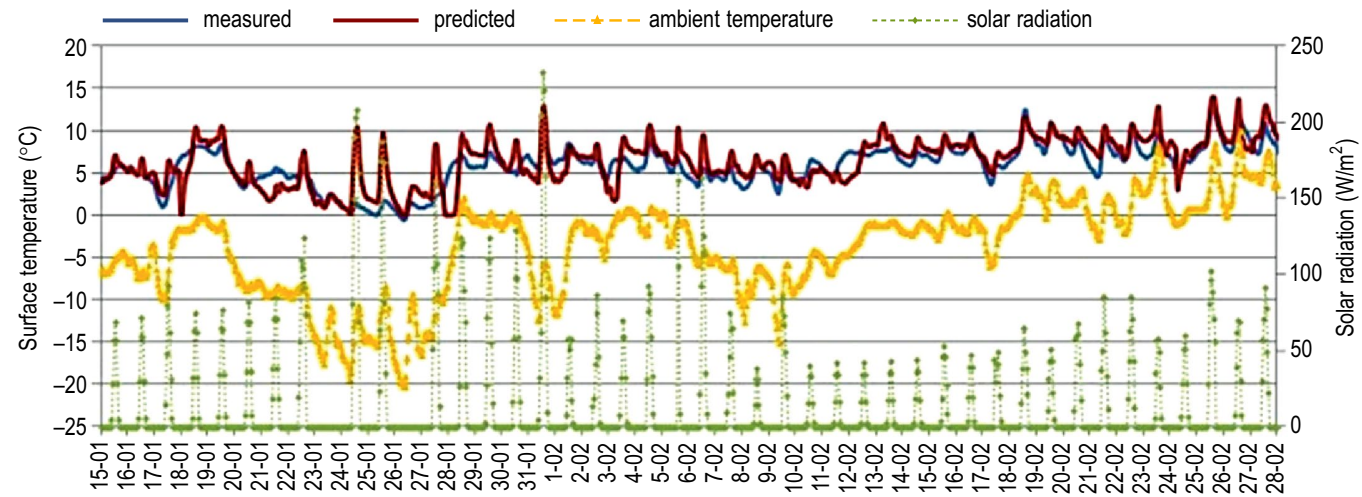

Fig. 7. Measured and predicted average surface temperature with ambient temperature and solar radiation

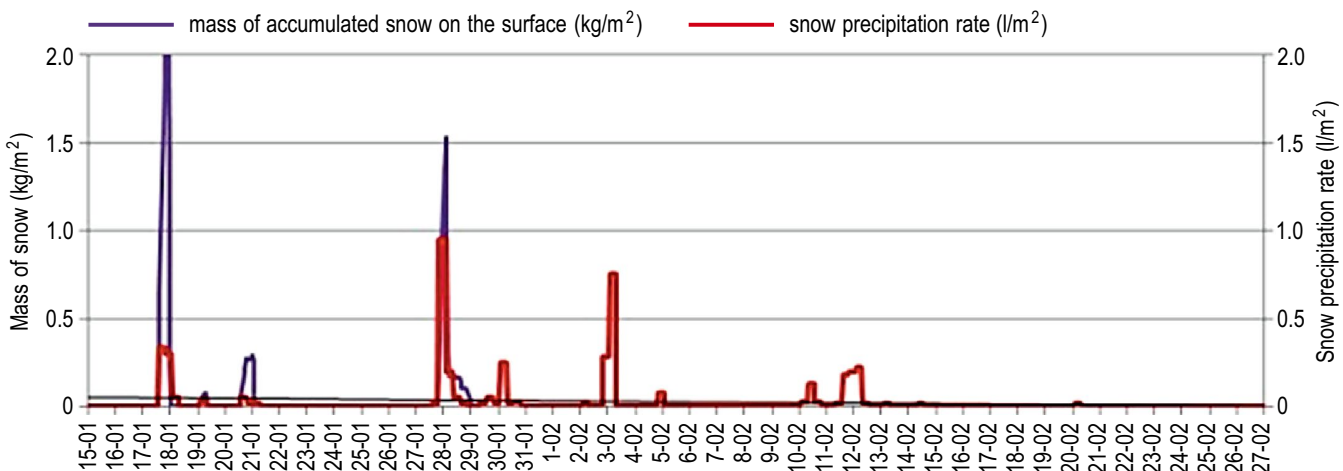

Fig. 8. Predicted mass of accumulated snow on the surface with the snow precipitation rate

to $10-15{ }^{\circ} \mathrm{C}$ when the solar radiation has been higher than $125 \mathrm{~W} / \mathrm{m}^{2}$. This tendency is shown in both the simulation and experimental results.

However model predicted a much higher temperature than the measurement data. This is particularly noticeable on 24.01 and 25.01. It could be due to the lack of real values of solar radiation. The calculation model of solar radiation overestimated the values of solar radiation about $10-15 \%$ on very sunny days and this was a period of high solar radiation and low air temperature when the surface was dry.

Uncertainties of relevance in the modelling were the values of material layers properties used in heating surfaces and weather data. The thermal conductivity, specific heat, and density of the material layers are important parameters that can significantly impact the heat diffusion inside the surface. These properties were not measured; they were adopted from published date, so they may be different from the actual values used in the experimental setup.

Besides, the experimental setup was surrounded by walls of expanded polystyrene plate as shown in Figure 4 , and that limited the effect of wind. Therefore calculation of convective fluxes may be in error due the applicability of correlations intended for flat plate situated at open space.

At the start of snowfall, according to the assumption used in the model, the predicted temperature of $0{ }^{\circ} \mathrm{C}$ was adopted. In fact, the surface temperature was bit lower.
Surface temperature was over-predicted in the period after melting, when the surface was clear of ice and snow but remained wet. This could be due to assumption used in the model that there was no water on the surface after all the ice has been melted.

The differences between measured and predicted temperature were varied about $2-5{ }^{\circ} \mathrm{C}$.

Despite those differences, the trends of rise and fall in predicted and measured temperatures were shown good agreement throughout all measuring range.

The comparison of measured and predicted results allows recommend this numerical simulation model for further research.

\section{Simulations results}

\subsection{Surface temperature}

Figures 9 and 10 show surface temperature resulting from $t_{\text {surf }}=3{ }^{\circ} \mathrm{C}$ and $t_{\text {surf }}=5{ }^{\circ} \mathrm{C}$ control strategy respectively.

As shown in those figures, the heating system tries to maintain set temperature at the surface. Nevertheless, the same figures show very clearly surface temperature fluctuating considerably over 24 hours - this is primarily down to solar radiation effect.

In practice, it would be good to evaluate the amount of time required by the temperature of surface to react to the solar radiation effects, because it could reduce the heating energy consumption by system. 


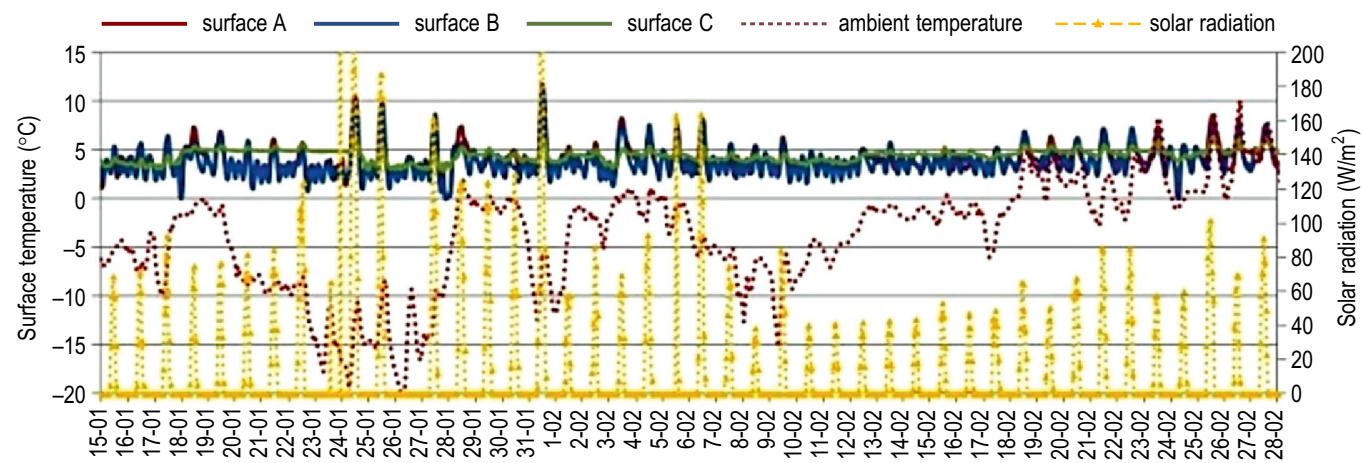

Fig. 9. Surface temperature for different heating surfaces resulting from control strategy $t_{\text {surf }}=3{ }^{\circ} \mathrm{C}$ with ambient temperature and solar radiation for investigated period

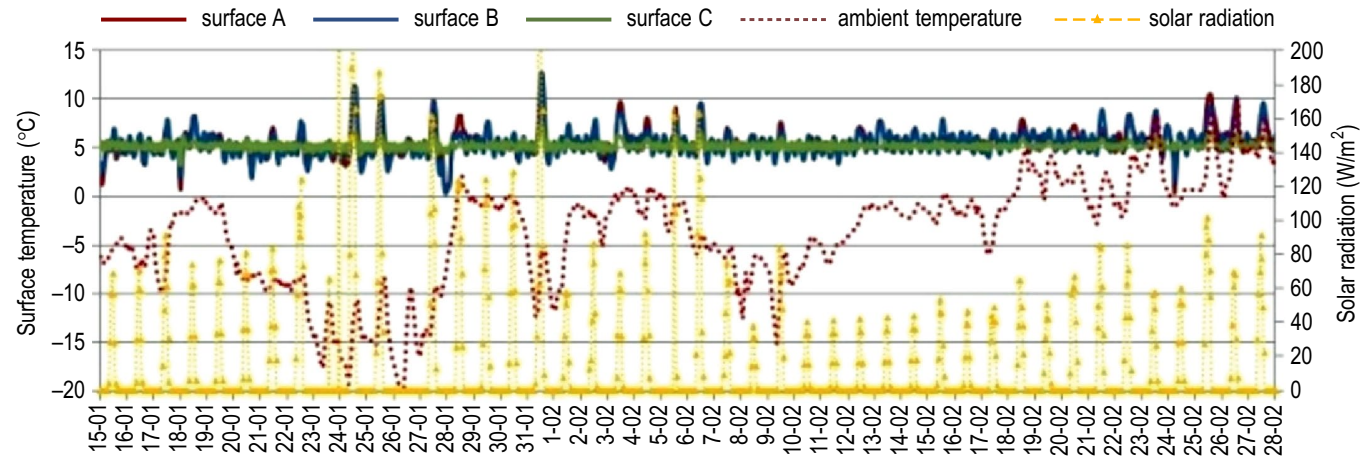

Fig. 10. Surface temperature for different heating surfaces resulting from control strategy $t_{\text {surf }}=5{ }^{\circ} \mathrm{C}$ with ambient temperature and solar radiation for investigated period

The difference between maximum and minimum temperature during twenty-four hours was taken as the indicator of surface temperature variability over a day $\Delta t_{\text {surf-max }}$ (maximum amplitude of fluctuation) and $\Delta t_{\text {surf-min }}$ (minimum amplitude of fluctuation). Table 3 shows minimum and maximum amplitudes of surface temperature that occurred over the investigated period. Substantially higher daily amplitude of surface temperature fluctuations was found for grass covered surfaces (heating surface A and B) compared to concrete surface (heating surface $C$ ), where smaller fluctuations were observed.

Bright surfaces such as heating surface $\mathrm{C}$ covered with concrete paving blocks of light grey colour reflect solar radiation. Their albedo is higher than the albedo of dark surfaces (e.g. green grass). For example, short grass has an albedo of 0.26 , while the albedo of concrete is

Table 3. Daily minimum and maximum amplitude of surface temperature fluctuations which occurred over the of investigated period

\begin{tabular}{cccc}
\hline Surface & $\mathrm{A}$ & $\mathrm{B}$ & $\mathrm{C}$ \\
\hline & control strategy $t_{\text {surf }}=3{ }^{\circ} \mathrm{C}$ \\
\hline amplitude min & $1.32^{\circ}$ & $2.07^{\circ}$ & $0.06^{\circ}$ \\
\hline amplitude max & $10.36^{\circ}$ & $9.64^{\circ}$ & $2.76^{\circ}$ \\
\hline \multicolumn{4}{c}{ control strategy $t_{\text {surf }}=5^{\circ} \mathrm{C}$} \\
\hline amplitude min & $1.59^{\circ}$ & $1.81^{\circ}$ & $0.55^{\circ}$ \\
\hline amplitude max & $10.61^{\circ}$ & $9.46^{\circ}$ & $2.79^{\circ}$ \\
\hline
\end{tabular}

0.59. Therefore, the effect of solar radiation on the surface temperature of concrete surface (heating surface $\mathrm{C}$ ) was less visible, and heating surface $\mathrm{C}$ was characterised by smaller surface temperature fluctuations.

\subsection{Supply temperature}

Figures 11 and 12 show fluctuations of supply temperatures for individual surfaces.

It is clear that grass covered surfaces A and B require higher supply temperatures than concrete covered surface $\mathrm{C}$. This is due to the fact then the concrete materials are characterised by greater heat capacity than soil. The greatest difference between required supply temperature for control strategy $t_{\text {surf }}=3{ }^{\circ} \mathrm{C}$ and $t_{\text {surf }}=5{ }^{\circ} \mathrm{C}$ was observed in case of surface $\mathrm{C}$. Surface $\mathrm{C}$ does not require heating at all to reach $t_{\text {surf }}=3{ }^{\circ} \mathrm{C}$, whereas increasing setting to $t_{\text {surf }}=5^{\circ} \mathrm{C}$, causes greater variability of supply temperature.

In case of heating surface $C$, very clearly increase of supply temperature is shown (Fig. 11). This is due to occurrence of snow on the surface. When the snow was appeared on the surface the surface temperature was decreased. The heating system trying to keep the set temperature on the surface had to provide more power, and thus operate at higher supply temperature.

By analysing together charts showing surface and supply temperatures one can note that surface heating system for open spaces is characterised by very high 


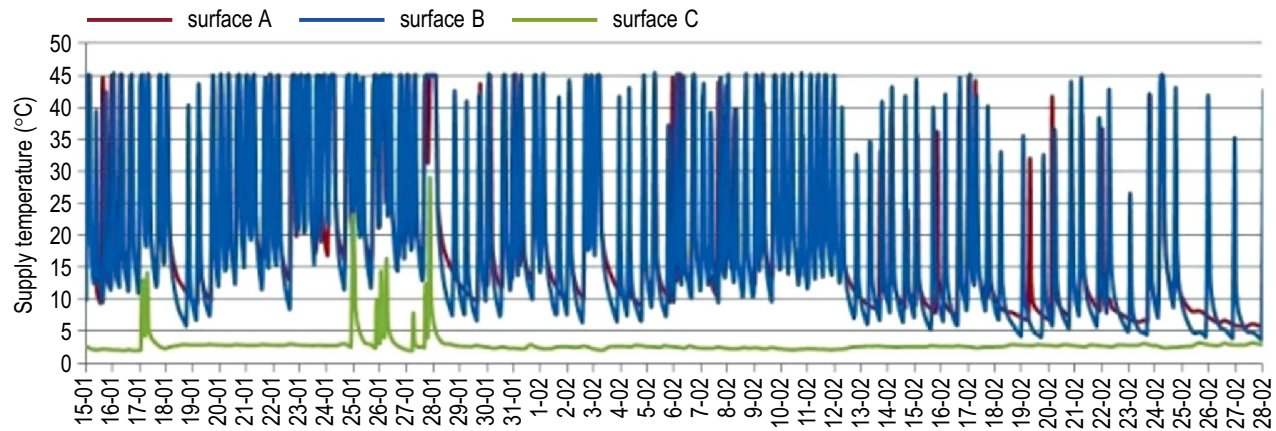

Fig. 11. Supply temperature for different heating surfaces resulting from control strategy $t_{\text {surf }}=3{ }^{\circ} \mathrm{C}$ for investigated period

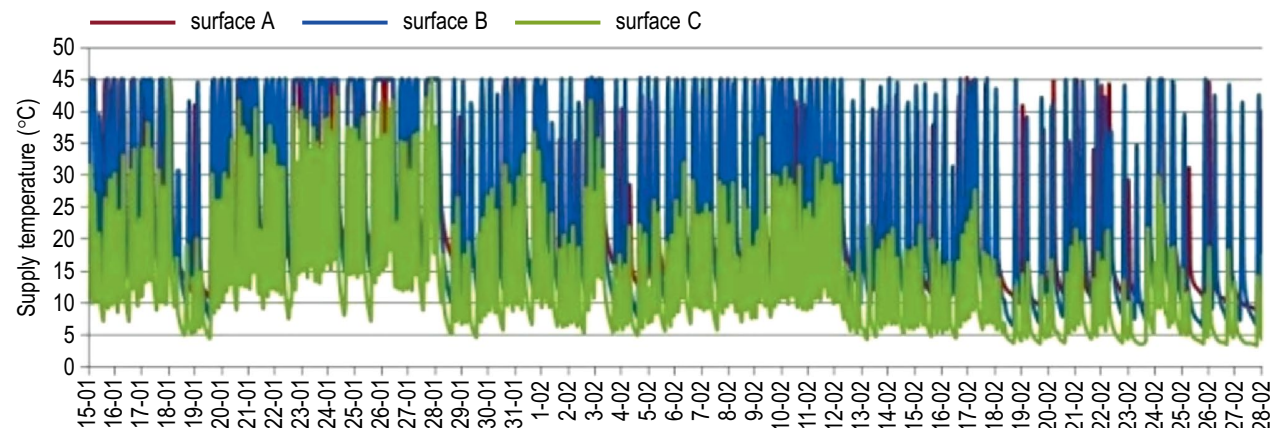

Fig. 12. Supply temperature for different heating surfaces resulting from control strategy $t_{\text {surf }}=5{ }^{\circ} \mathrm{C}$ for investigated period

inertia. Despite supply temperature decrease the system still exchanges the heat what causes the surface temperature to continue growing, occasionally even above set maximums of $t_{\text {surf }}=3^{\circ}$ or $t_{\text {surf }}=5^{\circ} \mathrm{C}$.

Large fluctuations of supply temperature shown in Figures 11 and 12 were caused by the adopted model of control strategy. In order to obtain a more regular supply temperature a different type of controller should be used.

Figures 13 and 14 show operation time as a function of supply temperature for individual surfaces in given control strategy.

These figures show how many hours did the system operates at given supply temperature over the investigated period. Once again we come to conclusion that heating surfaces covered with grass require higher supply temperatures over longer operating periods than concrete covered surfaces.

\subsection{Energy efficiency}

Energy efficiency is one of the most essential aspects of the designing and building of those systems.

Heating of surfaces at an open space is an energy balance between the heating medium, which is transferred through the coil and the layers of heating surface. The heat requirement for preventing snow accumulation and ice formation on these surfaces has been determined by the integration of multiple heat transfer process.

Table 4 presents a summary of energy consumption and characteristic parameters for individual simulations.

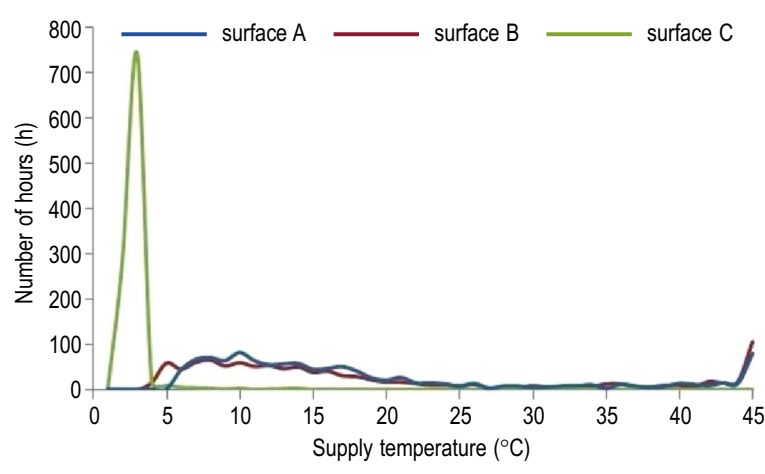

Fig. 13. Operation time as a function of supply temperature resulting from control strategy $t_{\text {surf }}=3{ }^{\circ} \mathrm{C}$

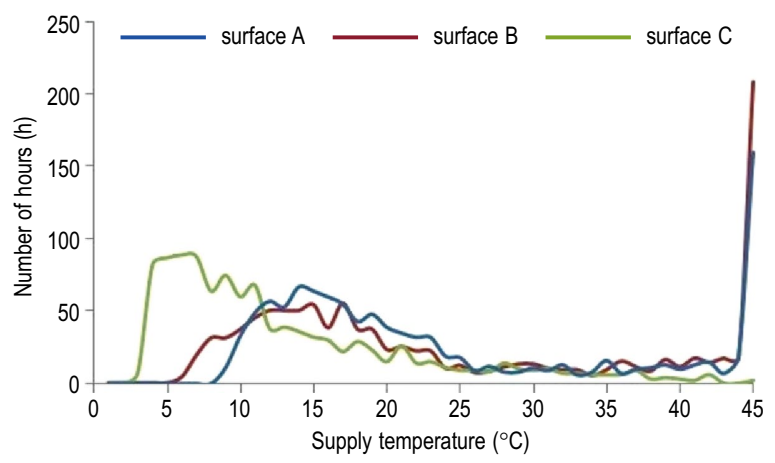

Fig. 14. Operation time as a function of supply temperature resulting from control strategy $t_{\text {surf }}=5{ }^{\circ} \mathrm{C}$ 
Table 4. Summary of simulation results for different heating surfaces

\begin{tabular}{|c|c|c|c|c|}
\hline 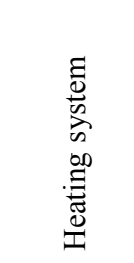 & 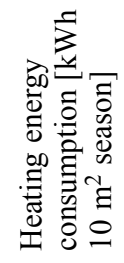 & 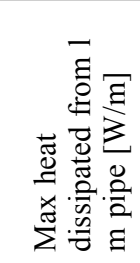 & 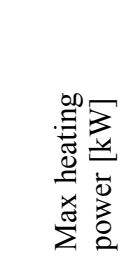 & 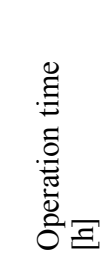 \\
\hline \multicolumn{5}{|c|}{ control strategy $t_{\text {surf }}=3{ }^{\circ} \mathrm{C}$} \\
\hline surface A & 648 & 82.2 & 4.10 & 315 \\
\hline surface B & 823 & 79.3 & 3.96 & 401 \\
\hline surface $\mathrm{C}$ & 15 & 37.8 & 1.89 & 15 \\
\hline \multicolumn{5}{|c|}{ control strategy $t_{\text {surf }}=5^{\circ} \mathrm{C}$} \\
\hline surface A & 873 & 82.6 & 4.13 & 386 \\
\hline surface B & 1082 & 84.4 & 4.21 & 431 \\
\hline surface $\mathrm{C}$ & 481 & 62.1 & 3.10 & 427 \\
\hline
\end{tabular}

Energy consumption over investigated period was shows in first column. It is product of summing up the heat flux from the coil multiplied by total coil length. Aggregated data was originally collected over the period from 15.01.2010 to 28.02.2010, i.e. 1080 hours. All results concern the same surface area of the surface heating system of $10 \mathrm{~m}^{2}$.

Maximum heat dissipated from $1 \mathrm{~m}$ pipe length over the course of investigation gives second column. Third column it is the maximum heat dissipated from whole coil.

Comparison between surfaces shows that heating surface B was the highest energy demanded, namely the grass covered surface where heating pipes were embedded in stabilised earth with concrete. This concerns surface temperature set to $t_{\text {surf }}=3{ }^{\circ} \mathrm{C}$ as well as $t_{\text {surf }}=$ $5{ }^{\circ} \mathrm{C}$. Energy consumption by heating surface A built identically to heating surface B apart from stabilised earth with concrete, was lower in both cases by an average of $200 \mathrm{kWh}$ per season. Identical maximum values of heat dissipated from $1 \mathrm{~m}$ pipe length were registered for heating surface A operating at $t_{\text {surf }}=3{ }^{\circ} \mathrm{C}$ and $t_{\text {surf }}=$ $5{ }^{\circ} \mathrm{C}$ settings. However, in order to maintain the higher surface temperature, system for heating surface A had to operate longer.

In case of heating surfaces set to $t_{\text {surf }}=3{ }^{\circ} \mathrm{C}$, higher heat power demand was observed for heating surface A compared to $\mathrm{B}$, whereas for setting $t_{\text {surf }}=5{ }^{\circ} \mathrm{C}$ the opposite was true. In both cases, system for heating surface $B$ operated longer than for heating surface A, partly because system for heating surface B operated at lower power. For setting $t_{\text {surf }}=3{ }^{\circ} \mathrm{C}$ difference in operation time was $86 \mathrm{~h}$, and for setting $t_{\text {surf }}=5{ }^{\circ} \mathrm{C}$ it was $45 \mathrm{~h}$.

Analysis of energy consumption by heating surface $\mathrm{C}$, namely the concrete paving stone covered surface shows that the heating surface does not operate when set to $t_{\text {surf }}=3{ }^{\circ} \mathrm{C}$, whereas set to $t_{\text {surf }}=5^{\circ} \mathrm{C}$ its energy consumption increased by $466 \mathrm{kWh}$ per season. Heating surface $\mathrm{C}$ itself does not have enough capacity to keep set surface temperature in that setting.

\section{Conclusions}

The effects of structural solutions on thermal energy efficiency of heating surface at an open space were evaluated.

Performed analyses have shown that the model of control strategy is closely related to the used structural solutions and has an impact on energy consumption of the system. In order to maintain the surfaces free of snow, for the surfaces covered with grass the work with a control strategy to maintain the surface temperatures $t_{\text {surf }}=3{ }^{\circ} \mathrm{C}$ is sufficient but for the concrete surface this temperature is not sufficient and higher temperature is needed.

The thermal conductivity of the different material layers used under the ground level of heating surfaces is significantly related to the thermal efficiency of surface heating system for open spaces. Respectively, larger the thermal conductivity of materials used for construction of heating surface at the same depth of embedded pipe, lesser the heating energy consumption. The most important are the layers where the pipes are embedded and the layers above them. Therefore, the thermal conductivity should be adjusted accordingly.

Moreover, open space heating systems are exposed to substantially time-varying weather conditions. Therefore, application accurate information of crucial parameters and weather data is of great importance to accurately simulate the performance of heating surface system at an open space.

Determining thermal energy efficiency of heating surface requires running numerous comparative analyses, just as determining optimal system parameters that will ensure minimum energy consumption. Numerical models are required for that purpose. They have to factor in heat transfer and mass transfer mechanisms as well as high variability of surface weather conditions.

\section{References}

ASHRAE. 2003. Handbook - HVAC applications. American Society of Heating, Refrigerating and Air-Conditioning Engineers, Atlanta, 2003, Chapter 50. 995 p.

Banionis, K.; Stankevičius, V.; Monstvilas, E. 2011. Heat exchange in the surface of lightweight steel roof coatings, Journal of Civil Engineering and Management 17(1): 88-97. http://dx.doi.org/10.3846/13923730.2011.556180

Banionis, K.; Monstvilas, E.; Stankevičius, V.; Bliūdžius, R.; Miškinis, K. 2012. Impact of heat reflective coatings on heat flows through the ventilated roof with steel coatings, Journal of Civil Engineering and Management 18(4): 505511. http://dx.doi.org/10.3846/13923730.2012.700943

Bliss, R. W. 1961. Atmospheric radiation near the surface of the ground, Solar Energy 5(3): 103-120. http://dx.doi.org/10.1016/0038-092X(61)90053-6

Chen, M.; Wu, S.; Wang, H.; Zhang, J. 2011. Study of ice and snow melting process on conductive asphalt solar collector, Solar Energy Materials and Solar Cells 95(12): 32413250. http://dx.doi.org/10.1016/j.solmat.2011.07.013

Chiasson, A. D.; Spitler, J. D.; Rees, S. J.; Smith, M. D. 2000. A model for simulating the performance of a pavement heating system as a supplemental heat rejecter with 
closed-loop ground-source heat pump systems, Journal of Solar Energy Engineering 122(4): 183-191.

http://dx.doi.org/10.1115/1.1330725

Faraouki, O. T. 1981. Thermal properties of soils. United States Army Corps of Engineers, Cold Regions Research and Engineering Laboratory, Hanover, New Hampshire, USA. $142 \mathrm{p}$.

Gao, Q.; Li, M.; Yu, M.; Spitler, J. D.; Yan, Y. Y. 2009. Review of development from GSHP to UTES in China and other countries, Renewable and Sustainable Energy Reviews 13(6-7): 1383-1394. http://dx.doi.org/10.1016/j.rser.2008.09.012

Gao, Q.; Young, H.; Li, M.; Liu, M.; Yan, Y. Y. 2010. Experimental study of slab solar collection on the hydronic system of road, Solar Energy 84(12): 2096-2102. http://dx.doi.org/10.1016/j.solener.2010.09.008

Incropera, F. P.; De Witt, D. P. 1996. Introduction to heat transfer. New York: John Wiley \& Sons. 832 p.

Kaczorek, D. 2011. Wpływ czynników klimatycznych i rozwiazań konstrukcyjnych na wydajność cieplna płaszczyzny grzejnej na otwartej przestrzeni [Influence of climatic factors and structural solutions on thermal energy efficiency of heating surface at an open space]: PhD Thesis. Poznan: Poznan University of Technology. 176 p. (in Polish).

Kamada, R. F.; Flocchini, R. G. 1986. Gaussian solar flux model, Solar Energy 36(1): 73-87. http://dx.doi.org/10.1016/0038-092X(86)90062-9

Kilkis, I. B. 1994. Design of embedded snow-melting systems: Part 2, Heat transfer in the slab - a simplified model, ASHRAE Transactions 100(1): 434-441.

Liu, X.; Rees, S. J.; Spitler, J. D. 2007. Modeling snow melting on heated pavement surfaces. Part I: Model development, Applied Thermal Engineering 27(5-6): 1115-1124. http://dx.doi.org/10.1016/j.applthermaleng.2006.06.017

Louche, A.; Maurel, M.; Simonnot, G.; Peri, G. 1987. Determination of Angstrom's turbidity coefficient from direct total solar irradiance measurements, Solar Energy 38(2): 89-96. http://dx.doi.org/10.1016/0038-092X(87)90031-4

Lund, J. W. 2000. Pavement snow melting, Geo-Heat Center, GHC Bulletin 21(2): 12-19.

Marszałek, K. 1993. Absorpcja promieniowania słonecznego przez dowolnie usytuowane płaszczyzny [Absorption of solar radiation by arbitrarily positioned plane], in Proc. of Fizyka Budowli w Teorii i Praktyce, 1993, Łódź, Poland, 177-187 (in Polish).

Mihalakakou, G. 2002. On estimating soil surface temperature profile, Energy and Buildings 34(3): 251-259. http://dx.doi.org/10.1016/S0378-7788(01)00089-5
Morita, K.; Tago, M. 2000. Operational characteristics of the GAIA snow-melting system in Ninohe, Iwate, Japan, GHC Bulletin 21(4): 5-11.

Nagai, N.; Miyamoto, S.; Nishiwaki, M.; Takeuchi, M. 2009. Numerical simulation of snow melting on pavement surface with heat dissipation pipe embedded, Heat Transfer-Asian Research 38(5): 313-329. http://dx.doi.org/10.1002/htj.20226

Penman, H. L. 1948. Natural evaporation from open water, bare soil, and grass, in Proc. of Royal Society, 1948, London, UK, A193: 120-146.

PN-EN ISO 10456:2009. Materiaty $i$ wyroby budowlane. Wtaściwości cieplno-wilgotnościowe. Tabelaryczne wartości obliczeniowe i procedury określania deklarowanych $i$ obliczeniowych wartości cieplnych. [Building materials and products. Hydrothermal properties. Tabulated design values and procedures for determining declared and design thermal values]. Polish Standards Institute, 2009. 31 p. (in Polish).

Rees, S. J.; Spitler, J. D.; Xiao, X. 2002: Transient analysis of snow-melting system performance, ASHRAE Transactions 108(2): 406-423.

REHAU. 2012. International sports venue construction with REHAU [online], [cited 10 January 2013]. Available from Internet: http://www.rehau.com/group_en/Press/ Special European_Championship 2012/96076̄/international_sports_venue_construction.html.

Sękowski, K.; Juchnicki, J. 2004. System KAN-Therm ogrzewanie powierzchni otwartych [System KAN-Therm open spaces heating] [online]. Warszawa, 2004 [cited 10 January 2013]. Available from Internet: http://pl.kan-therm. com/kan/upload/por_powierzchni\%20otw_luty\%202004. pdf.

Tabares-Velasco, P. C.; Srebric, J. 2012. A heat transfer model for assessment of plant based roofing systems in 4 summer conditions, Building and Environment 49(1): 310 323. http://dx.doi.org/10.1016/j.buildenv.2011.07.019

Wang, H.; Zhao, J.; Chen, Z. 2008. Experimental investigation of ice and snow melting process on pavement utilizing geothermal tail water, Energy Conversion and Management 49(6): 1538-1546.

http://dx.doi.org/10.1016/j.enconman.2007.12.008

Wu, S. P.; Chen, M. Y.; Wang, H.; Zhang, J. 2009. Laboratory study on solar collector of thermal conductive asphalt concrete, International Journal of Pavement Research and Technology 2(4): 130-136.

Dobroslawa KACZOREK. Doctor, Adjunct at the Department of Heating, Air Conditioning and Air Protection at Poznan University of Technology (Poland), PhD in 2011 at Poznan UT. Research interests include heat transfer, outdoor climate, numerical modelling.

Halina KOCZYK. Professor, Doctor Habil at the Department of Heating, Air Conditioning and Air Protection at Poznan University of Technology (Poland). PhD in 1978, habilitation in 1990 at Poznan UT. Research interests include heat transfer in buildings, energy savings, internal environment, energy storage. 